\title{
Asian Perspective of Population 2019: A Sociological Appraisal
}

\author{
Mohammad Taghi Sheykhi \\ Professor Emeritus of Sociology, Alzahra University, Tehran, Iran \\ mtshykhi@alzahra.ac.ir
}

\section{Abstract}

The present attempt fulfills the urgent need of researchers in the valuable field of sociology, economics and statistics. The author has gathered the material from various sources of population data. As data on fertility, mortality and migration are ever changing, sociologists and demographers need to compare and analyze population change and structure every now and then, to introduce and build up new strategies leading to favorable population status. In this way, remedies and reforms could be reached wherever possible. In order to enable the readers to have a comparative image of growth of population in Asia, an abridged table has been provided. Such a comparative study is necessary to understand population problems in Asia with about $60 \%$ of world population. Factors affecting population distribution are know as geographic, social, economic and demographic. One of the most important aspects of population study in modern time is the tempo of urbanization which is the result of population growth.
Keywords

population growth; urbanization; cultural change; population analysis, aging

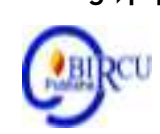

\section{Introduction}

Change is an inevitable part of our lives through different stages. In population science, change is through childhood, teenage, adulthood and old age. and through such process, people usually access primary, secondary, and partly tertiary education. Such developments bring about further changes for the population. Likewise, human population has witnessed the transformation of human society from preliterate to modern literate societies. Human societies have also evolved from primitive hunting and gathering stages to agrarian industrial societies followed by the stage of post-modern society. Cultural change and civilizations have also appeared and disappeared throughout the history, or so to say, history has witnessed a large number of rises and falls. Human beings have widely witnessed changes in their productivity and childbearing--increasing births, increasing deaths and migrations. Therefore, human society has ever almost been dynamic and not static. The entire such process has always been accompanied by social problems for the human society. Thus, the human society ever needs adaptive strategies to solve the created problems. Here in the current research, some of the population problems will be analyzed in sociological terms. Tough first the social or population change occurred to the Western Europe in the 18th and 19th centuries, yet later it happened to Asia as well. However, it should e kept in mind that the study of population helps the improvement of many other disciplines. Updated data of surveys and censuses help educationists, food suppliers, housing planners, environmentalists and many more areas. 


\section{Research Methods}

Methodology used in the current research is a combination of procedures in qualitative context. More broadly, qualitative method which is increasingly a popular method of research in social sciences has been applied to do the research. To conduct the present research, the following techniques and tools have been employed:

1. Books, documents and other relevant sources of information.

2. Observation: The researcher used this method too, through visiting people and institutions to delve the data needed to build up the article.

3. Interview: Interviews were mainly conducted to find ideas, probe responses, and investigate feelings which questionnaires can never do.

Through such qualitative method, some ideas, attitudes, feelings and behavior vis-a-vis the question were sought in order to assess the issues. This flexible method was used as a means to reach the goal of Asian perspective of population in 2019.

\section{Discussion}

\subsection{Population Analysis}

Asia as the largest continent of the world with a population of 4,587 billion and inclusive of over 50 independent countries, is almost growing population-wise, leaving behind challenges and issues which need sociological analysis and assessment. Issues currently faced by the Asian countries include the followings among others:

\section{a. Aging}

The two processes of modernization and industrialization have played major parts in aging of the Asian countries. However, aging being a natural or passive process involves social exclusion in societies (Turner, 2001). Demographic characteristics of human populations are clearly of major importance for any sociological understanding of human society. Despite these obvious connections between demography and sociology, it is surprising that these two disciplines have tended to develop as separate and distinct approaches to human society (Wrigley and Schofield, 1982); (Coleman and Salt, 1992).

The ignorance of demographers and sociologists about each other's disciplines has now been partly dispelled with recent developments in the social history of human population, which is constantly concerned with questions as marriage practice, family structure, fertility, mortality and migration.

\section{b. Increasing Popullation}

Demographic transition as a theory specifies the general laws by which human populations change in size structure with special reference to industrialization. The theory holds that in the pre-industrial societies both death rate and birth rate were high, and in that, population was stagnant. In the first stage death rate began to fall, followed by improvements in nutrition, food supply, food distribution, and improvements in health standards and sanitation. Since the birth rate continues to remain high relative to the declining death rate, rapid increase in population size emerge (Wrong, 1966); (Andorka, 1978).

So, after the population increase, deprivation or so to say, an inequality of access to social goods and services appeared (Brown and Madge, 1982). Thus low income or unemployment would culminate in poor housing, poor health, and access to inferior education. 
Other problems emerging from increasing population size would include de-schooling and de-skilling observed within certain groups of population in Asian societies. Many such societies are not in a position to cover the educational needs of some parts of their populations, and that would lead to a cycle of poverty which ultimately leads to not having access to professional skills.

Another problem originating from population large size is known as deviance. Creation of a spiral of deviance increasingly becomes problematic and repeated in an amplifying manner. Therefore, population needs to be controlled quantitatively and qualitatively (Ditton, 1979). Deviant behavior also as observed in the society as a result of deviant behavior could be reflected in drug offenders. Countries with a surplus population generally face a problem (Lemert, 1951).

\section{c. Economic Phenomena}

Economic sociology as a broad field of sociology covers many substantive economic phenomena, is widely related to quantitative and qualitative population. It includes all aspects of the economic activities of individuals and groups, consumption, leisure, economic effects of different cultures, markets, economic institutions etc. Size and structure of population is highly related to the nature of economic life. At present, and in consuming societies, countries need to have the population that can be materially and non-materially fed and adjusted to the economic construct of the relevant society. However, contemporary economic sociologists advocate a sociological analysis of all economic issues. Similarly, a comparison of economic sociology with economics helps define the sociological approach.

\section{d. Fertility}

Natural fertility is the fertility which exists in the absence of any deliberate birth control. On the other hand, the fertility which involves a deliberate use of birth control, is the practice currently taking place. After industrialization increasing number of methods of birth control have emerged, and by the means of which a great number of births have been prevented such as abortions, sterilization etc. Many of such methods have been used in Asian countries since 1950, and if not, population would have been much more, while death rate has highly fallen. Therefore, fertility refers to the actual reproductive performance applied to an individual or a group. On the other hand, fecundity refers to capacity of a man, a woman, or a couple to participate in reproduction (i.e. the reproduction of a live child). Fertility can be measured through birth rate. Fecundity however cannot be measured. It refers to the maximum fertility level that can be attained. However, those who have not produced any child are called sterile. In modern time, as many young people marry late, the rate of sterility has gone up in many parts of Asia. Family size was large in the past and in previous generations since more fertility used to happen and the average marriage age was lower than the current time.

\section{e. Death Rate}

Crude death rate is the number of deaths per 1000 population per year. In modern time, due to improvements in medical sciences and medical services, death rate has decreased. Under such a situation, people have found better chance to live longer. This is the main root of increasing life expectancy, and as a result, increasing aging people emerge. Now that the birth rate and death rate have mainly narrowed, many countries are facing low rate of natural population increase. This phenomenon happened to the Western world earlier than Asia. The result of the phenomenon is higher quality of life for them, and increase in per capita of many items and essentials from food to housing etc. 


\section{f. Migration}

The most important component of population change, other than mortality and fertility, is migration. Migration mainly happens due to economic reasons followed by political reasons. Currently other reasons have contributed to migration to take place such as environmental, drought and the like. Migration increases with industrialization and improvement in transportation--the main cause being economic. Migration is a consequence of (negative) push and (positive) pull factors. Migration is intensifying due to population increase in the Third World countries. It has persuaded the political decision-makers to gather and decide about it. Low wages in developing countries is motivating increasing number of people to migrate to the industrial countries as a pull factor.

However, the character of migration is changing with globalization, labor market, and the graying of population of the advanced countries. The study of migration is important due to the following reasons:

1 It determines the size and rate of population growth as well as its its structure and characteristics.

2 It decreases or increases the size and structure of any population drastically.

3 It plays an important role in the distribution of population of any country. Thus, it is useful in preparing regional projections.

4 It determines the growth of labor force in any area.

5 It is the symptom of basic social change in any country.

6 It is related to business cycle, supply of skilled and unskilled workers.

7 It is the basis for the analysis and solution of social and psychological problems arising out of population changes, particularly large scale migration.

According to United Nations Multilingual Demographic Dictionary, "Migration is a form of geographical mobility or spatial mobility between one geographical unit and another generally involving a change in residence from the place of origin or place of departure to the place of determination or place of arrival" (Sharma, 1991). Migration defined here is permanent type as distinguished from other forms of movement.

Table 1. Selected Population Variables of Some Asian Countries 2019

\begin{tabular}{|c|c|c|c|c|c|c|c|}
\hline $\begin{array}{c}\text { Continent/ } \\
\text { Countries }\end{array}$ & $\begin{array}{c}\text { Population } \\
\text { (millions) } \\
\text { mid-2019 }\end{array}$ & $\begin{array}{c}\text { Births } \\
\text { Per 1000 } \\
\text { population }\end{array}$ & $\begin{array}{c}\text { Deaths Per } \\
\mathbf{1 0 0 0} \\
\text { population }\end{array}$ & $\begin{array}{c}\text { Rate of } \\
\text { Natural } \\
\text { Increase (\%) }\end{array}$ & $\begin{array}{c}\text { Population } \\
\text { (millions) } \\
\text { mid 2050 }\end{array}$ & $\begin{array}{c}\text { \% } \\
\text { Population } \\
\text { Ages 65+ }\end{array}$ & $\begin{array}{c}\text { \% } \\
\text { Urban }\end{array}$ \\
\hline Asia & 4.587 & 19 & 6 & 1.3 & 5.344 & 9 & 49 \\
\hline $\begin{array}{c}\text { Saudi } \\
\text { Arabia }\end{array}$ & 34.2 & 16 & 3 & 1.3 & 47 & 3 & 84 \\
\hline Turkey & 82.6 & 15 & 5 & 1.0 & 104.6 & 9 & 75 \\
\hline Afghanistan & 38.0 & 33 & 7 & 2.7 & 70.7 & 3 & 25 \\
\hline India & 1.391 .9 & 20 & 6 & 1.3 & 1.669 .7 & 6 & 31 \\
\hline Iran & 83.9 & 19 & 5 & 1.5 & 113.3 & 6 & 74 \\
\hline Pakistan & 216.6 & 29 & 7 & 2.2 & 368.9 & 4 & 37 \\
\hline Philippines & 108.1 & 11 & 6 & 1.5 & 144.5 & 5 & 47 \\
\hline China & 1.398 .0 & 11 & 7 & 0.4 & 1.367 .4 & 12 & 60 \\
\hline Korea. S & 51.8 & 6 & 6 & 0.1 & 47.7 & 15 & 82 \\
\hline
\end{tabular}

Source: 2019 World Population Data Sheet.

\subsection{Fuiture Status}

The above-mentioned countries of Asia and many more will be facing increasing problems of housing, employment, food supply, environmental degradation, migration, 
family breakdown and many more socio-economic problems. However, many more unpredicted problems may emerge for the increasing populations of those countries. What such countries need is futurology to look at the future possibilities based on current trends. At the time being, countries must see their positions for the mid of 21 st century, and if not, they will face various challenges and hardships at that time.

One of the most important institutions of mankind has been family during the human history. So, if conditions and settings are not favorable, the stability of institution will be in danger, and so poverty and deviance will emerge __ leading to other issues. Such circumstances will not only happen to Asia with $60 \%$ of the world population, but to Africa to a larger extent. Therefore, countries need to pay high attention to their population trends. Countries like China and South Korea have well planned their populations and attained their goals. So, other countries in Asia may follow suit. Sociology as the basic study of society emphasizes on attaining social order, and it could be achieved only if we have an orderly stable population, stable families and satisfactory economic patterns. Sociology of development involves the perfect perspective of population in Asia. So, the applicationof sociological concepts and methods to the analysis of the production, exchange, and consumption of goods and services is highly related to population quality and quantity (Britannica, 2019).

\section{Conclusion}

As inevitably changes emerge in human life, population policies and plans are needed to be put into action. Dynamism of human society needs populations adaptive to resources, and if not, the human population will face challenges and poverty in various contexts. Population patterns always need to be monitored, appraised and analyzed especially when electronics is substituting the human power and skills. Asia currently having over 4.5 billion population, is facing increasing problems of employment, food supply, shortage of water resources, inevitable migration, environmental degradation, pollution and many more problems. Other issues faced by Asia include aging, early marriages, and late marriages in increasing instances. Social pathologists are concerned about the problems and abnormalities emerging in these countries due to speedy cultural change, and the gap created between generations. In the course of demographic transition in Asia, death rate is declining while birth rate is almost at a static rate. Therefore, adaptive strategies need to be adopted. Migration too due to economic reasons is largely taking place in Asia creating densely urban areas with increasing socio-environmental problems. The only countries well planned in terms of population are China and South Korea in Asia.

\section{References}

Abidin, Said Zainal. (2014). Kebijakan Publik. Jakarta: Salemba Humanika.

Agustino. (2013). Efektifitas Kebijakan dalam konteks administrasi publik. Jakarta: Rineka Cipta.

Anggara, Sahya. (2014). Kebijakan Publik. Bandung: CV. Pustaka Setia.

Bangun, Wilson. (2014). Manajemen Sumber Daya Manusia. Bandung: Erlangga. 
Bohlander, George., \& Snell, Scott. (2014). Principles of Human Resource. Management, 15 th ed. Mason, OH: South Western-Cengage Learning.

Bungin, Burhan. (2014). Penelitian Kualitatif. Jakarta: Kencana Predana MediaGroup.

Dessler. (2013). Manajemen Sumber Daya Manusia Human Reources.Jakarta: Prenhalindo.

Faisal, Sanapiah. (2014). Format-Format Penelitian Sosial. Jakarta: Raja Grafindo Persada.

Griffiths, Ricky W dan Ebert, Ronald J. (2014). Bisnis. Jakarta: Erlangga.

Hamzah, Utami. (2013). Pendekatan Kualitatif Bagi Peneliti Pemula. Jakarta: PT Raja Grafindo Persada.

Hasibuan, Malayu S.P. (2013). Manajemen Sumber Daya Manusia, Edisi Revisi. Jakarta: Bumi Aksara.

Mangkunegara, Anwar Prabu. (2013). Manajemen Sumber Daya ManusiaPerusahaan. Bandung: Remaja Rosda Karya.

Moleong, Lexy J. (2014). Metode Penelitian Kualitatif. Bandung: PT Remaja Rosdakarya.

Mulyana, Dedy. (2014). Metodologi Penelitian Kualitatif Paradigma Baru Ilmu Komunikasi Dan Ilmu Sosial Lainnya. Bandung: Remaja Rosdakarya.

Musanef. (2016). Memahami Good Governance. Yogyakarta: Gava Media.

Nugroho, Riant. (2016). Public Policy. Jakarta: Gramedia.

Rivai, Veithzal. (2014). Kepemimpinan dan Perilaku Organisasi. Edisi ke Empat. Jakarta: PT. Raja Grafindo Persada.

Simamora, Henry. (2014). Manajemen Sumber Daya Manusia. Yogyakarta: STIE YKPN.

Sugiyono. (2016). Metode Penelitian Kualitatif. Bandung: Alfabeta.

Sulistiyani, A.T. dan Rosida. (2013). Manajemen Sumber Daya Manusia: Konsep, Teori dan Pengembangan dalam Konteks Organisasi Publik. Yogyakarta: Garaha Ilmu.

Tatang, Suherman. (2014). Metodologi Penelitian Kualitatif. Jakarta: PT Raja Grafindo Persada.

Thoha, Miftah. (2014). Birokrasi Pemeritahan Indonesi di Era Reformasi. Yogyakarta: Media Widya Mandala.

Torang, Syamsir. (2014). Organisasi dan Manajemen (Perilaku, Struktur, Budaya, \& Perubahan Organisasi). Bandung: CV. Alfabeta.

Usman, Budiman. (2014). Sistem Administrasi Pemerintahan Daerah. Jakarta: Bumi Aksara. 